\title{
Elimination of Tomato Spotted Wilt Virus (genus Tospovirus) From Infected Tomato Plants by Meristem Tip Culture
}

\author{
M. AlKhazindar \\ Botany and Microbiology Department, Faculty of Science, \\ Cairo University, Egypt.
}

\begin{abstract}
7 OMATO plant (Lycopersicon esculentum Mill.) is an economically important crop in Egypt and rest of the world. Tomato Spotted Wilt Virus (TSWV, family Bunyaviridae, genus Tospovirus) is a common tomato-infective virus in Egypt. The elimination of TSWV by meristem tip culture without other treatment was studied. Virus-free plants were obtained when using meristem tips smaller than $0.5 \mathrm{~mm}$. Optimal tissue culture and propagation protocol was established. Elimination of TSWV was indexed and authenticated by Immuno Capture Reverse Transcriptase Polymerase Chain Reaction (IC/RT-PCR). The combination of an efficient protocol for virus elimination from infected plants and the establishment of a sensitive diagnostic test resulted in the production of tomato plants free from TSWV.
\end{abstract}

Keywords: IC/RT-PCR, TSWV, Meristem tip culture, Virus elimination.

Lycopersicon esculentum Mill. (tomato) is one of the most economically important crop worldwide (Chaudhry et al., 2010). It has high nutritional value and is used either fresh or processed. Tomato plants are highly vulnerable to several bacterial, fungal, phytoplasmal and viral diseases thus affecting the productivity of tomato crop (Chaudhry et al., 2010). Forty different virus diseases have been reported to infect tomato (Martelli and Quacquarelli, 1982 and Alam et al., 2004). Tospoviruses are among the 10 most detrimental plant viruses worldwide (Soellick et al., 2000). Tomato spotted wilt virus (TSWV) family Bunyaviridae, genus Tospovirus is one of the most important diseases affecting tomatoes, occasionally leading to losses up to $100 \%$ (Roselló et al., 1996). TSWV was first reported in Egypt in 1999 infecting Physalis peruviana (AlKhazindar, 2000). It was recorded to infect more than 1100 different plant species belonging to 70 botanical families leading to a significant economic impact in ornamental plants, vegetables, and field crops (EPPO, 1999 and AlKhazindar, 2000).

Several attempts have been made to eliminate virus infection and to improve crop production (Riley and Pappu, 2000 and Narayanasamy, 2013). The tissue culture technique is effective in eradicating viruses from infected plants and for the production of high quality and virus-free plants (Palana et al., 2005 and

malkhazi@aucegypt.edu 
Osman et al., 2010). A wide range of infected plants have been successfully established virus-free using the tissue culture technique. Such technique is accomplished either alone (Verma et al., 2004 and Ram et al., 2005), or combined with chemotherapy and thermotherapy (Kumar et al., 2009). TSWV has been successfully eliminated using meristem tip culture technique from different infected plants such as Arachis spp. (Dunbar et al., 1993) and Impatiens hawkerii (Milošević et al., 2011).

Serological indexing using enzyme linked immunosorbent assay (ELISA) is routinely used for the detection of viruses in infected plants. Nevertheless, ELISA lacks the sensitivity required for the detection of viruses and is not considered a reliable technique especially when detecting low virus levels in plant tissues (AlKhazindar et al., 2011). Nolasco et al. (1993) improved a method combining Immuno Capture (IC) and PCR amplification in a microtiter plate for the detection of plant viruses. IC/RT-PCR provides a possible alternative to ELISA, which fails because of low titer, inhibitory compounds and cross reactivity of antibodies with heterologous antigens (Jain et al., 1998 and Ulubas and Ertunc, 2005). Inhibitors as a limiting factor in PCR amplification may be present in certain plant tissues (Vunsh et al., 1991) therefore, diluting plant sap for IC/RT-PCR is one of the means of overcoming this difficulty (Rosner et al., 1998). Such test obviates the need for the time consuming RNA purification step which simplifies RT-PCR assay. Therefore, it is important to use a highly sensitive and accurate technique especially when testing mother stocks to authenticate the absence of virus.

In our study, plant meristem culture technique was carried out to develop a protocol for producing virus-free tomato clones. This will help to produce TSWV-free tomato plants which are a prerequisite to grow high quality and healthy crop. The production of TSWV-free tomato plants is validated by IC-RT PCR.

\section{Plant material}

\section{Material and Methods}

Lycopersicon esculentum Mill. showing brown spots, blistering, stunting and wilting were collected from a farm in Giza governorate, Egypt. Infected plants were back-inoculated and maintained in a greenhouse. Plants were examined for the presence of TSWV using IC/RT-PCR.

\section{Oligonucleotide Primers and Immunoglobulin}

The primers and the IgG used in this study were produced by AlKhazindar (2006). Primers were designed according to the conserved sequence of the nucleoprotein gene of TSWV (TSWV-N) amplifying $\approx 777$ bp fragment of the small (S RNA) segment.

TSWV forward (5' ATGTCTAAGGTTAAGCTC 3').

TSWV reverse (5' TTAAGCAAGTTCTGTGAG 3').

TSWV polyclonal antiserum was raised against the recombinant nucleoprotein gene expression strategy AlKhazindar (2006).

Egypt. J. Bot., 55, No. 1 (2015) 
Immunocapture Reverse Transcription Polymerase Chain Reaction (IC/RT-PCR)

Different samples of tomato (infected leaves and in vitro grown cultures) were ground $(1: 10 \mathrm{w} / \mathrm{v})$ in extraction buffer [2\% PVP, $0.2 \%$ skimmed dried milk in PBS]. The mixture was centrifuged at $5000 \mathrm{xg}$ for $3 \mathrm{~min}$. Equal volumes of the plant extract supernatant were added to the PCR tubes previously coated with $50 \mu \mathrm{l}$ of $\mathrm{IgG}$. The mixture was incubated overnight at $4{ }^{\circ} \mathrm{C}$ and then washed with PBST. The RT reaction was carried out using TSWV forward primer followed by PCR according to Sambrook et al. (1989). PCR amplification was carried out in a thermal cycler (Eppendorf, Germany) for 35 cycles under the following conditions: denaturation at $94^{\circ} \mathrm{C}$ for $45 \mathrm{sec}$., annealing at $45^{\circ} \mathrm{C}$ for $1 \mathrm{~min}$. and extension at $72^{\circ} \mathrm{C}$ for $90 \mathrm{~min}$. PCR products were visualized by gel electrophoresis in $1.5 \%$ agarose gel stained with ethidium bromide.

\section{Establishment of aseptic culture}

TSWV-infected shoot tips of tomato plants were cut to be used as explants for initiation of meristem culture. Shoot tips were thoroughly washed in running water for $30 \mathrm{~min}$., and were later washed in double distilled (d.d.) water. The tips were filtered through cheese cloth and dipped in $1 \% \mathrm{NaOCl}$ solution containing four drops of Tween-20 for $15 \mathrm{~min}$. The tips were rinsed with sterilized d.d. water 4-5 times in the laminar-air flow. After sterilization, the leaf primordia surrounding the meristematic bud were carefully excised to expose the meristem $(0.1-0.7 \mathrm{~mm})$ using a sterilized binocular microscope. The explants were implanted on agar basal MS medium (Murashige and Skoog 1962) $\mathrm{pH} 5.8$, supplemented with $1.0 \mathrm{mg} \mathrm{L}^{-1} \mathrm{BA}$. Forty meristem tips of the same size were placed into ten tissue culture jars, four meristem tips into each jar. The cultures were maintained in the growth chamber under 16 -h photoperiod provided by cool white florescent tubes at $25 \pm 2{ }^{\circ} \mathrm{C}$ and relative humidity $70-80 \%$. After sprouting, the developed callus and regenerated shoots were sub cultured and were later transferred on half strength solid MS medium supplemented with $1.0 \mathrm{mg} \mathrm{L}^{-1}$ IBA for rooting according to Osman et al. (2010). The regenerated plants were monitored and examined weekly to detect any virus infection using IC/RT-PCR.

\section{Plant acclimatization}

Regenerated plantlets with fully developed leaves and differentiated root were taken out of the jars. The agar was removed using sterilized d.d. water and the plantlets were transferred to formaldehyde-sterilized plastic plug trays filled with autoclaved peat moss and were covered with a clear plastic lid, and incubated at 16-h photoperiod, $25 \pm 2{ }^{\circ} \mathrm{C}$ and $70 \%$ air humidity. Seven days later, the plants were acclimatized to ambient humidity levels by gradually removing the lid over a 2-day period. Plants developed were visually screened for symptoms and were weekly examined for the presence of TSWV using IC/RT-PCR.

\section{Results}

TSWV Symptoms on Lycopersicon esculentum Mill.

The first characteristic symptom appeared was in the form of small dark spots. As growth continued, leaves wilted, turned brown and died. Infection 
caused growth decline especially in the growing tips and the plant became stunted (Fig.1). Green fruits showed dark spots, irregular ripening and reduced fruit set.

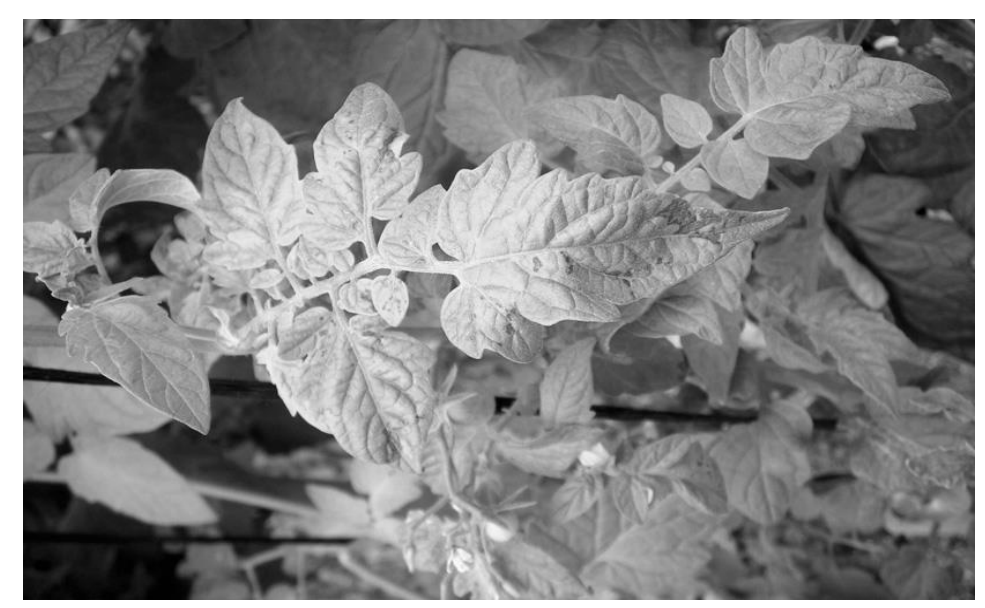

Fig. 1. Tomato spotted wilt virus-induced symptoms in tomato.

\section{Meristem culture and plant regeneration}

Excised L. esculentum apical meristem tip $(0.2-0.7 \mathrm{~mm})$ increased in size and formed a callus within 4-5 weeks of culture which later sprouted showing shoot differentiation. Approximately 3 shoots $(2-3 \mathrm{~cm}$ long) emerged from each cultured meristem. All meristem tips (size $0.1 \mathrm{~mm}$ ) turned brown and died, while $50 \%$ survival rate was obtained from meristem tips (size $0.2 \mathrm{~mm}$ ). Larger tips (size 0.3-0.7 mm) showed 100\% survival rate (Table 1). Sub-cultured shoots were further transferred into half strength media supplemented with $1.0 \mathrm{mg} / \mathrm{L}$ IBA for rooting (Fig. 2).

TABLE 1. Regeneration efficiency of different sizes of meristem tips and indexing of the presence of tomato spotted wilt virus during tomato development by Immuno Capture Reverse Transcriptase Polymerase Chain Reaction.

\begin{tabular}{|c|c|cc|}
\hline $\begin{array}{l}\text { Size of meristem } \\
(\mathbf{m m})\end{array}$ & $\begin{array}{c}\text { Regenerated number of } \\
\text { cultures and the survival } \\
\text { percentage } \\
\text { (number of survived } \\
\text { cultures/total) }\end{array}$ & $\begin{array}{c}\text { Number of virus-free cultures } \\
\text { and percentage of virus } \\
\text { elimination (Virus-free/total) }\end{array}$ \\
\hline 0.1 & $0 / 40(0 \%)$ & - & $(0 \%)$ \\
\hline 0.2 & $20 / 40(50 \%)$ & $20 / 20$ & $(100 \%)$ \\
\hline 0.3 & $40 / 40(100 \%)$ & $40 / 40$ & $(100 \%)$ \\
\hline 0.4 & $40 / 40(100 \%)$ & $40 / 40$ & $(100 \%)$ \\
\hline 0.5 & $40 / 40(100 \%)$ & $30 / 40$ & $(75 \%)$ \\
\hline 0.6 & $40 / 40(100 \%)$ & $0 / 40$ & $(0 \%)$ \\
\hline 0.7 & $40 / 40(100 \%)$ & $0 / 40$ & $(0 \%)$ \\
\hline
\end{tabular}

Egypt. J. Bot., 55, No. 1 (2015) 

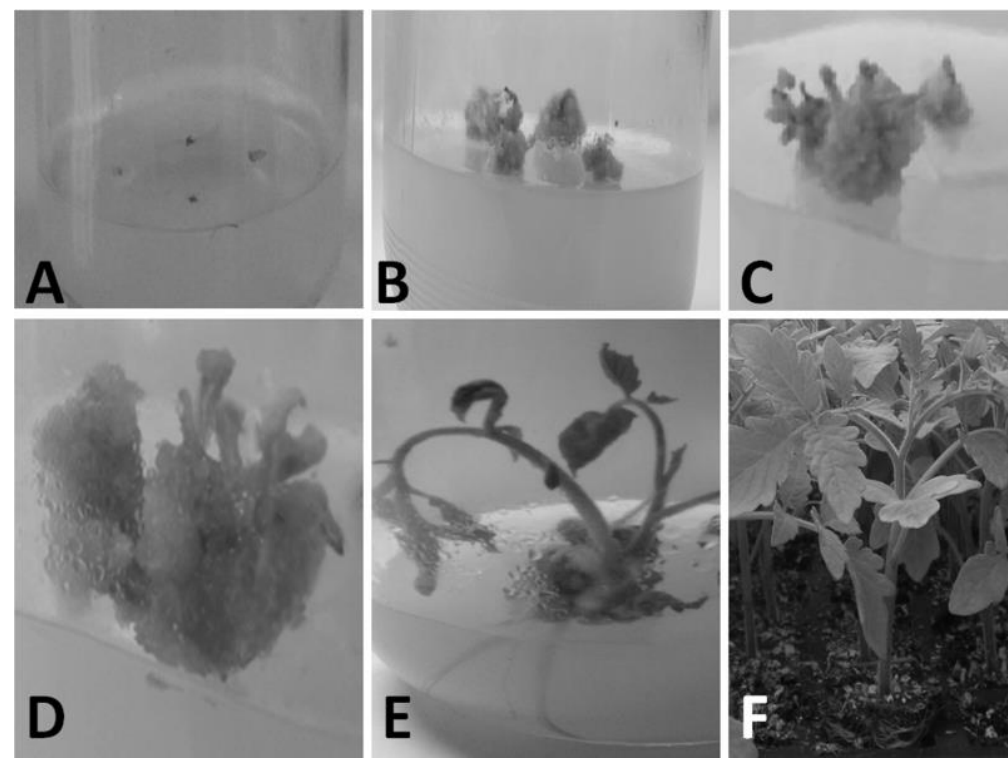

Fig. 2. Development of tomato plants from meristem tip explants to a regenerated plantlet for the production of tomato spotted wilt virus-free plants. (A) excised meristem tip in MS culture media, (B) callus formation, (C) callus regeneration, (D) initiation of proliferation of shoots with callus, (E) development of shoots accompanied with rooting, (F) regenerated tomato plants in the green house after acclimatization.

\section{Molecular indexing}

Cultures were regularly tested for the presence of TSWV using IC/RT-PCR. Molecular indexing did not show the same virus-free result for the specimens tested. Although all meristem sources were infected, explants $(0.2-0.4 \mathrm{~mm})$ were all $100 \%$ virus-free during all stages of development. During the development of explants size $(0.5 \mathrm{~mm}), 75 \%$ of them were virus-free. However, none of the larger sized regenerated explants $(0.6-0.7 \mathrm{~mm})$ were free of virus and were all excluded from the experiment (Table 1). Gel electrophoresis visualized the amplification of $\approx 777 \mathrm{bp}$ DNA fragment which was obtained in all samples initiated from large meristem tips $(0.6-0.7 \mathrm{~mm})$ as in the positive control, however, samples initiated from explants smaller than $0.5 \mathrm{~mm}$ did not show any amplification. TSWV was not eliminated in all samples originating from meristem tips size 0.5 as determined by IC/RT-PCR (Fig. 3 ).

\section{Plants acclimatization}

The regenerated plants were successfully acclimatized and were later transferred to the soil (Fig. 2.F). The developed plants were all symptomless and $100 \%$ TSWV-free when tested using IC/RT-PCR. 


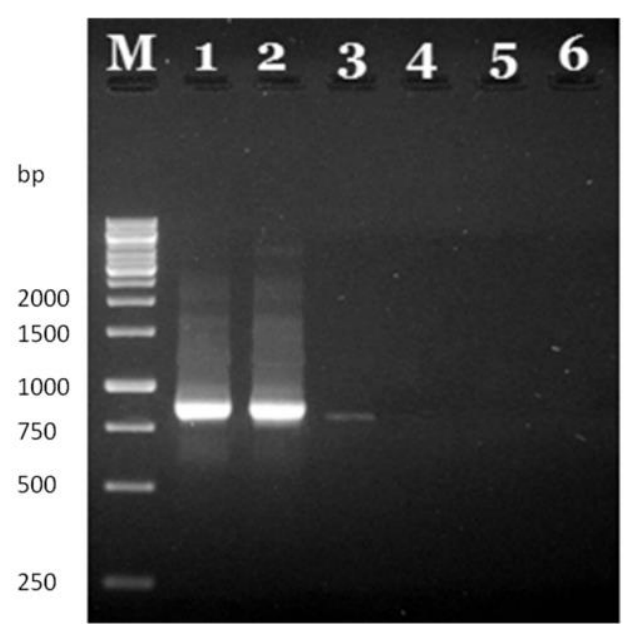

Fig. 3. Gel electrophoresis of Immuno Capture Reverse Transcriptase Polymerase Chain Reaction products for the detection of tomato spotted wilt virus in in vitro cultures of tomato plants. Lanes $1-3$ show an amplicon of $\approx 777 \mathrm{bp}$ in tissues derived from meristem tips size $(0.7,0.6 \& 0.5)$ respectively. Lanes 4 6: tissues derived from meristem tips size $(0.4,0.3 \& 0.2)$ respectively showing no amplification. M: GeneRuler ${ }^{\mathrm{TM}} 1 \mathrm{~kb}$ DNA ladder.

\section{Discussion}

In the present study, the elimination of TSWV infection from tomato plants was successfully accomplished using the micro shoot tip culture technique. Previous studies have successfully eliminated viral infection using meristem culture, chemotherapy and thermotherapy either alone or in combination. However, chemotherapy has proved to cause phytotoxicity on treated plants (Griffiths et al., 1990). Furthermore, tomato plants are known to be highly sensitive to heat and our previous trials using thermotherapy have failed due to the death of the explants, this made us exclude chemotherapy and thermotherapy, and the meristem tip culture was used without further treatment.

Virus elimination using in vitro culture is attributed to several reasons: a) the action of growth regulators -specifically cytokinin- (Barlass and Skene, 1982), b) cell injury during excision that causes loss of the enzymes required for viral replication and RNA degradation (Mellor and Stace-Smith, 1977), c) poor development of vascular tissue in the meristematic cells and slow movement of virus particles from cell to cell compared to the rate of growth of the meristematic cells (Parmessur et al., 2002), d) the descending virus concentration from the base of the plant towards the meristems which may show its lowest titer or may fail to exist in the meristematic tissues (Wang and Valkonen, 2008). The later is attributed to the immature vascular elements of the leaf primordia that are not yet connected to the differentiated vascular tissues of the stem.

Egypt. J. Bot., 55, No. 1 (2015) 
Different protocols have been developed for the production of tomato plants from apical shoot tips using several combinations of auxin and cytokinin (Bhatia et al., 2004 and Chaudhry et al., 2010). Regeneration of shoots can either be obtained directly from meristem tip (Dwivedi et al., 2014) or indirectly through an intermediate callus phase (Geetha et al., 1998). In fact, both callus and shoots may be produced together (Bhatia et al., 2004). This is in accordance with current findings where meristem tips cultured in MS media and supplemented with $1.0 \mathrm{mg} / \mathrm{L}$ BA grew satisfactorily and established the formation of callus within 4-5 weeks of culture which sprouted into differentiated shoots. Marks and Simpson (1994) suggested that callus formation may be due to the action of accumulated auxins at the basal cut ends which stimulates cell proliferation, especially in the presence of cytokines. This hypothesis seems to hold true with the obtained results where callus was initiated with a combination of the BA added (cytokine) and the naturally contained auxin. Different growth regulators are usually used for maximum regeneration. However, in this study, callus formation and shoot regeneration from meristem tip culture originated using $1 \mathrm{mg} / \mathrm{l}$ BA. Shoot cultures produced roots without the addition of auxin. Mensuali-Sodi et al. (1995) found that tomato plants have high level of endogenous auxin, and do not require the addition of growth regulators to achieve the regeneration of roots. However, using $1.0 \mathrm{mg} / \mathrm{L}$ IBA on half strength MS for root formation was successful in this study and showed accelerated root induction which is in accordance with Panathula et al. (2014) who showed that IBA facilitates maximum rooting efficiency for rhizogenesis. Current findings are also similar to Devi et al. (2008) who reported that the best tomato rooting was obtained on half strength IBA.

In this study, micro shoot tips (below $0.5 \mathrm{~mm}$ ) lead to callus formation and were efficient in the virus elimination from infected plants. Larger explants (above $0.6 \mathrm{~mm}$ ) were all infected and were excluded. These results are in agreement with Verma et al. (2004) and Wang and Valkonen (2008) who confirmed that the efficiency of virus eradication depends on the size of shoot tips excised. Furthermore, small meristems are more tedious to excise, they lead to callus formation and the rate of regeneration is lower than large sized tips, but they were proven to successfully eradicate the virus (Facciolo and Marani, 1998). Sim and Golino (2010) and Parmar et al. (2013) also reported that macro shoot tips are not reliable to eliminate virus infections which are in accordance to our results.

In this research, IC/RT-PCR was used to detect the presence of TSWV during the development of the in vitro cultures. TSWV was not eliminated in all samples originating from meristem tips size 0.5 . IC/RT-PCR was more sensitive since the same samples were tested using DAS-ELISA and showed negative results. This was attributed to the amplification of RNA of the trapped virion by immunoglobulin which concentrates and pre-purifies the virus particles. Regenerated cultures were successfully acclimatized under green house conditions. The method used was simple and inexpensive after taking all the precautions of sterilization and acclimatization. However, successful transfer of 
regenerated plants into the green house required extensive time and care to decrease the humidity. During acclimatization, plantlets were frequently tested for TSWV using IC/RT-PCR. The developed plants were all symptomless and $100 \%$ TSWV-free.

In this current research, an efficient protocol for TSWV elimination from infected tomato plants was accomplished using micro-meristem tip cultures smaller than $0.5 \mathrm{~mm}$. Indexing was done using IC/RT-PCR which proved to be a sensitive technique for authenticating the absence of the virus in the produced plants. This method proved to be reliable in producing good quality tomato plantlets for farmers.

\section{References}

Alam, M.F., Banu, M.L.A., Swaraz, A.M., Parvez, S., Hossain, M., Khalekuzzaman, M. and Ahsan, N. (2004) Production of virus free seeds using meristem culture in tomato plant under tropical conditions. Journal of Plant Biotechnology, 6: 221-227.

AlKhazindar, M. (2000) Studies on a virus naturally infecting Physalis peruviana. M.Sc. Thesis, Botany Department, Faculty of Science, Cairo University.

Alkhazindar, M. (2006) Serological and Molecular Studies on Tomato Spotted Wilt Virus. Ph.D. Thesis in Microbiology, Botany Department, Faculty of Science, Cairo University.

AlKhazindar, M., ElSayed, T. and Habib, H. (2011) Detection of Tomato spotted wilt virus using Immunocapture Reverse Transcription Polymerase Chain Reaction (IC/RT-PCR). $4^{\text {th }}$ Conference of the International Working Group on Legume and Vegetable Viruses (IWGLVV) Antequera (Málaga, Spain) May 17th-20th.

Barlass, M. and Skene, K.G.M. (1982) In vitro plantlet formation from Citrus species and hybrids. Scientia Horticulturae, 17 (4): 333-341.

Bhatia, P., Ashwath, N., Senaratna, T. and Midmore, D. (2004) Tissue culture studies of tomato (Lycopersicon esculentum). Plant cell tissue and organ culture, 78:1-21.

Chaudhry, Z., Abbas, S., Yasmin, A., Rashid, H., Ahmed, H. and Anjum, M. (2010) Tissue culture studies in tomato (Lycopersicon esculentum) var. Moneymaker. Pakistan Journal of Botany, 42: 155-163.

Devi, M., Dhaliwal, M.S., Kaur, A. and Gosal, S.S. (2008) Effect of growth regulators on in vitro morphogenetic response of tomato. Indian Journal of Biotechnology, 7: 526- 530.

Dunbar, K.B., Pinnow, D.L., Morris, J.B. and Pittman, R.N. (1993) Virus elimination from interspecific Arachis hybrids. Plant Disease, 77: 517-520.

Dwivedi, N.K., Indiradevi, A., Asha, K.I., Asokan, R. and Suma, A. (2014) A protocol for micropropagation of Aloe vera L. (Indian Aloe) - a miracle plant. Research in Biotechnology, 5:1-5.

Egypt. J. Bot., 55, No. 1 (2015) 
EPPO (1999) Tomato spotted wilt tospovirus. EPPO Bulletin, 29: 465-472.

Faccioli, G. and Marani, F. (1998) Virus elimination by meristem tip culture and tip micrografting. In: "Plant Virus Disease Control" Hadidi, A., Khetarpal, R.K., Koganezawa, H. (Eds.), APS Press Publishers, St. Paul, Minnesota, pp. 346-380.

Geetha, N., Venkatachalan, P., Reddy, P.S. and Rajaseger, G. (1998) In vitro plant regeneration from leaf callus cultures of tomato (Lycopersicum esculentum Mill.). Advanced Plant Science, 11: 253-257.

Griffiths, H.M., Slack, S.A. and Dodds, J.H. (1990) Effect of chemical and heat therapy on virus concentrations in in vitro potato plantlets. Canadian Journal of Botany, 68:1515-1521.

Jain, R.K., Pappu, S.S., Pappu, H.R., Culbreath, A.K. and Todd, J.W. (1998) Molecular diagnosis of tomato spotted wilt tospovirus infection of peanut and other field and greenhouse crops. Plant Disease, 82:900-904.

Kumar, S., Khan, M.S., Raj, S.K. and Sharma, A.K. (2009) Elimination of mixed infection of Cucumber mosaic and Tomato aspermy virus from Chrysanthemum morifolium Ramat. cv. Pooja by shoot meristem culture. Scientia Horticulturae, 119: 108-112.

Marks, T.R. and Simpson, S.E. (1994) Factors affecting shoot development in apically dominant Acer cultivars in vitro. Journal of Horticultural Sciences, 69: 543-551.

Martelli, G.P. and Quacquarelli, A. (1982) The present status of tomato and pepper viruses. Acta Horticulturae, 127: 39-64.

Mellor, F.C. and Stace-Smith, R. (1977) Virus free potatoes by tissue culture. In: "Applied and Fundamental Aspects of Plant Cell, Tissue and Organ Culture". J. Reinert and Y.P.S. Bajaj (Eds.). Springer-Verlag, Berlin, pp. 616-635.

Mensuali-Sodi, A., Panizza, M. and Tognoni, F. (1995) Endogenous ethylene requirement for adventitious root induction and growth in tomato cotyledons and lavandin microcutting in vitro. Plant Growth Regulator, 17: 205-212.

Milošević, S., Subotic, A., Bulajic, A., Djekic, I., Jevremovic, S., Vucurovic, A. and Krstic, B. (2011) Elimination of TSWV from Impatiens hawkerii Bull. and regeneration of virus-free plant. Electronic Journal of Biotechnology, 4: 1-10.

Murashige, T. and Skoog, F. (1962) A revised medium for the rapid growth and bioassays with tobacco cultures. Physiology Plantarum, 15: 473-497.

Narayanasamy, P. (2013) "Biological Management of Diseases of Crops": Volume 2: Integration of Biological Control Strategies with Crop Disease Management Systems Springer Science \& Business, Technology \& Engineering - Library of Congress Control Number: 2013932136. Springer science and business Media Dordrecht, pp. 251-253 ISBN 978-94-007-6376-0. 
Nolasco, G., De Blas, C., Torres, V. and Ponz, F. (1993) A method combining immunocapture and PCR amplification in a microtiter plate for the detection of plant viruses and subviral pathogens. Journal of Virological Methods, 45: 201-218.

Osman, M.G., Elsadig, A.E. and Mutasim, M.K. (2010) Callus formation and organogenesis of tomato (Lycopersicon esculentum Mill, cv. Omdurman) induced by thidiazuron. African Journal of Biotechnology, 9: 4407-4413.

Panathulam, C.S., Mahadev, M.D. and Naidu, C.V. (2014) High efficiency adventitious indirect organogenesis and plant regeneration from callus of Centella asiatica (L.) -An important Antijaundice medicinal plant. International Journal of Advanced Research, 2: 1027-1036

Parmar, V.R., Patel, H.A. and Jasrai, Y.T. (2013) Developing normal plants of Clerodendron from viral infected stock through meristem culture. Cibtech Journal of Bio-Protocols, 2: 1-5.

Parmessur, Y., Aljanabi, S., Saumtally, S. and Dookun-Saumtally, A. (2002) Sugarcane yellow leaf virus and sugarcane yellows phytoplasma: Elimination by tissue culture. Plant Pathology, 51: 561-566.

Palana, D., Marta, A., Regla, M.L., Marilyn, F., Alvarez, F. and Moya, C. (2005) A new in vitro regeneration protocol in tomato (Lycopersicon esculentum). Cultivos Tropicales, $26: 17-20$.

Ram, R., Verma, N., Singh, A.K., Singh, L., Hallan, V. and Zaidi, A.A. (2005) Indexing and production of virus-free chrysanthemums. Biologia Plantarum, 49: 149152.

Riley, D.G. and Pappu, H.R. (2000) Evaluation of tactics for management of thripsvectored tomato spotted wilt tospovirus in tomato. Plant Disease, 84: 847-852.

Roselló, S., Díez, M.J. and Nuez, F. (1996) Viral diseases causing the greatest economic losses to the tomato crop. I. The tomato spotted wilt virus. Scientia Horticulturae, 67: 117-150.

Rosner, A., Maslenin, L. and Spiegel, S. (1998) Differentiation among isolates of prunus necrotic ringspot virus by transcript conformation polymorphism. Journal of Virological Methods, 74: 109-115.

Sambrook, J., Fritsch, E.F. and Maniatis, T. (1989) Molecular cloning. A laboratory manual. "Cold Spring Harbor Laboratory", Cold Spring Harbor, NY.

Sim, S.T. and Golino, D. (2010) Micro vs. macroshoot tip tissue culture therapy for disease elimination in grapevines. Foundation Plant Services (FPS) Grape Program Newsletter 12-15.

Soellick, T.R., Uhrig, J.F., Bucher, G.L., Kellmann, J.W. and Schreier, P.H. (2000) The movement protein NSm of tomato spotted wilt tospovirus (TSWV): RNA binding, interaction with the TSWV N protein and identification of interacting plant proteins. Plant Biology, 97: 2373-2378.

Egypt. J. Bot., 55, No. 1 (2015) 
Ulubas, C. and Ertunc, F. (2005) Apple chlorotic leaf spot virus (ACLSV) status of Turkey and sensitive detection and using advanced techniques. Turkish Journal of Agricultural Forestry, 29: 251-257.

Verma, N., Raja, R., Hallan, V., Kumar, K. and Zaidi, A.A. (2004) Production of Cucumber mosaic virus-free chrysanthemums by meristems tip culture. Crop Protection, 23: 469-473.

Vunsh, R., Rosner, A. and Stein, A. (1991) Detection of bean yellow mosaic virus in gladioli corms by the polymerase chain reaction. Annals of Applied Biology, 119: 289294.

Wang, Q.C. and Valkonen, J.P.T. (2008) Elimination of two viruses which interact synergistically from sweet potato by shoot-tip culture and cryotherapy. Journal of Virological methods, 154: 135-145.
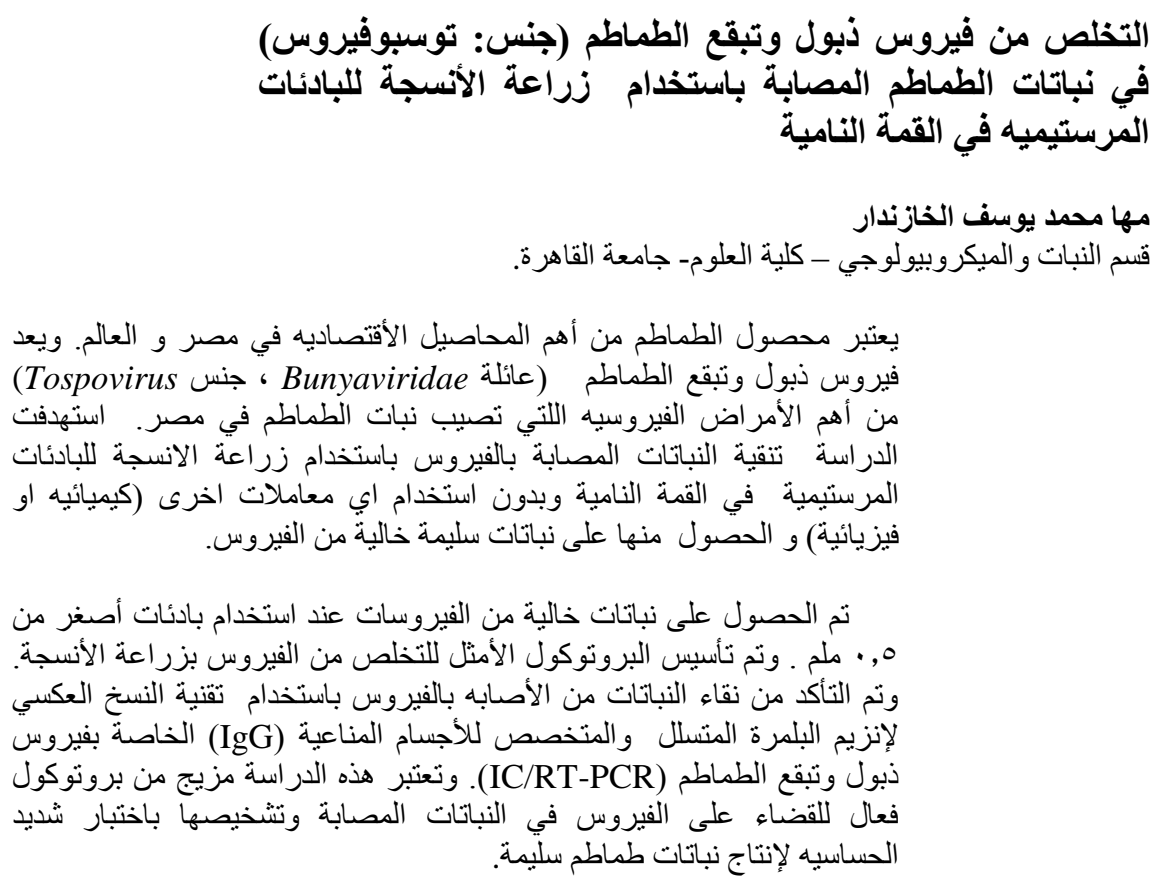